Editorial

\title{
Civil Society Elites: A Research Agenda
}

\author{
Håkan Johansson ${ }^{1, *}$ and Anders Uhlin ${ }^{2}$ \\ ${ }^{1}$ School of Social Work, Lund University, 22100 Lund, Sweden; E-Mail: hakan.johansson@soch.lu.se \\ 2 Department of Political Science, Lund University, 22100 Lund, Sweden; E-Mail: anders.uhlin@svet.lu.se \\ * Corresponding author
}

Submitted: 12 August 2020 | Published: 4 September 2020

\begin{abstract}
This editorial introduces the thematic issue on 'civil society elites,' a topic that has been neglected in elite research as well as civil society studies. It elaborates on the concept of 'civil society elites' and explains why this is an important emerging research field. By highlighting different methodological approaches and key findings in the contributions to the thematic issue, this article aims at formulating an agenda for future research in this field.
\end{abstract}

\section{Keywords}

capital; civil society; civil society elite; elites

\section{Issue}

This editorial is part of the issue "Civil Society Elites" edited by Håkan Johansson (Lund University, Sweden) and Anders Uhlin (Lund University, Sweden).

(C) 2020 by the authors; licensee Cogitatio (Lisbon, Portugal). This article is licensed under a Creative Commons Attribution 4.0 International License (CC BY).

The phenomenon of 'civil society elites' has not received much scholarly interest either in elite or civil society studies. Social science has a long interest in elites, as a means to describe and understand resource distribution, systems of social stratification and mechanisms that lead to concentration of power in societies (Hartmann, 2007; Savage \& Williams, 2008; Scott, 1996). Scholars often define elites as the small group(s) of individuals who "have vastly disproportionate control over or access to a resource" (Khan, 2012, p. 361). Elites are in that respect groups of individuals who 'possess' substantial amounts of resources valuable to others. One can also define elites as linked to positions that allow some individuals authority to exercise influence over others (Scott, 2008). Elites are in this respect defined by the position they occupy, for instance in political, administrative or business institutions. These two definitions of elites are in practice often mutually reinforcing as substantial resources allow access to key positions, and vice versa (Hartmann, 2007).

Whereas we find substantial literature on various elite groups (e.g., 'political elites,' 'business elites,' 'administrative elites' or 'religious elites'), few studies have focused on those at the top of civil society and hence in positions to exercise substantial influence over other civil society actors, the issue areas they are engaged in or even over societal developments. This is an increasingly relevant topic to address considering current developments within civil societies. Although civil society is a vast and diverse field embodying actors with different interests, small groups of civil society organizations (CSOs) have come to occupy central positions that allow them to dominate others. They tend to hold status positions that allow them to control valuable resources, such as money, information, expertise and knowledge or ability to mobilize extensive numbers of people to push for policy change. They also enjoy prestige and status within, but also beyond civil society and their particular area of concern. They furthermore often have a 'seat at the table' to discuss pressing issues (e.g., climate change, inequality, health, migration and human rights). Well-known organizations like Greenpeace, Amnesty, Oxfam, Friends of the Earth, World Wildlife Foundation and Caritas are examples and can be seen as having significant influence within their issue areas as well as beyond. Such concentration of valuable resources has not remained unchallenged. Civil society is a field where actors compete over 
valuable resources and central positions, and today social movement and grassroots mobilizations do not only target political and business leaders, but also civil society leaders, for having traded their democratic function as watchdogs against states and markets for prestige and status in new contexts. There is also a growing debate on the lack of diversity at the top level of major CSOs.

There is however a lack of systematic analyses of individuals who hold top positions in civil society, leaders who control vast resources and are part of networks of power and influence inside and also outside civil society sectors. Despite that civil society studies is a mature field of research, we have limited knowledge on issues like: Who are those in leading positions, what avenues lead into positions of power and how are their positions challenged? The notion of 'civil society elites' thus opens up a new strand of research, with regard to both civil society and elite studies. Much current civil society research addresses how states tame, manufacture or coopt CSOs, how political influence are potentially traded in exchange for legitimacy or alternatively how CSOs mobilize and organize against governments. While some research has paid attention to conflicts and power inequalities within civil society, this has seldom been analysed in terms of status and elites. In parallel, much elite research neglects civil society as a sphere sufficiently institutionalized to embody elite positions and elite groups, and generally considers civil society as a societal sphere lacking the resources and capacities associated with traditional elites or being the sphere where the 'real' elites interact as they take on positions to improve their public legitimacy as doing good and contributing to society.

The contributions to this thematic issue challenge such conventional academic understandings. The thematic issue contains studies from Northern and EastCentral Europe to Southeast Asia, and also in the supranational context of the EU. In their combined effort, the contributors show that civil society elites can be found across the world. The different contributions also apply various methods to study civil society elites, ranging from statistical analysis of survey data (Gulbrandsen, 2020) via qualitative analysis of biographical data on individual civil society leaders (Lindellee \& Scaramuzzino, 2020) to qualitative interviews (the other contributions).

Based on the different contributions we find that processes of civil society elitisation occur across regime types - in consolidated democracies such as Norway and Sweden as well as in newer and more contested democracies such as Poland and Indonesia, and in increasingly authoritarian states such as Cambodia. This is a striking finding suggesting that a civil society elite phenomenon is not only linked to particular political, social and geographical contexts.

Processes of elitisation take place in formal CSOs, such as NGOs, and more informal networks and platforms, as demonstrated in the Cambodian case (NorénNilsson \& Eng, 2020). A particular type of civil society elites can be found among think tanks, although they do not necessarily self-identify as belonging to the civil society field, as shown in articles by Åberg, Einarsson, and Reuter (2020) and by Jezierska (2020).

Four of the contributions (Haryanto, 2020; Lay \& Eng, 2020; Lindellee \& Scaramuzzino, 2020; Norén-Nilsson \& Eng, 2020) draw explicitly on Bourdieu's field theory and the related concept of capital. This approach is useful because it sheds light on relations of conflict and cooperation within civil society and how different power resources are valued, gained and used by civil society actors, thus indicating how and why certain actors emerge as elites.

In their study of career trajectories of 17 leaders of EU-based peak CSOs, Lindellee and Scaramuzzino (2020) derive a set of skills, types of capital, and forms of recognition and status that characterize the EU civil society field. They find that specific EU career trajectories are prominent among directors of Brussels-based umbrella organizations whereas the presidents of these organizations tend to have a more mixed-often nationalbackground. Expert knowledge plays an important role in the environmental sector, whereas an activist background is more salient in the social policy area.

The field approach also allows for analyses of how the civil society field relates to state and economic fields. As demonstrated by Lay and Eng (2020), state regulation of civil society may have different implications for the formation of civil society elites. In post-authoritarian Indonesia, state regulations have led to civil society elitisation through the formalisation and bureaucratisation of CSOs. Competition for formal positions has intensified, resulting in a plural civil society elite. Similar processes in increasingly authoritarian Cambodia have reduced the space for elite competition and created a monolithic 'hyper-elite' within civil society who are loyal to the regime.

A field approach also opens up for analyses of elite mobility between spheres and several articles in this thematic issue (Gulbrandsen, 2020; Haryanto, 2020; Norén-Nilsson \& Eng, 2020) examine how 'boundary crossers' move between civil society and other fields. Norén-Nilsson and Eng (2020) explore pathways to leadership within and beyond Cambodian civil society. They identify different forms of capital required to reach elite status in civil society and explore pathways of boundary crossing from civil society to the state, electoral politics and economic fields. In doing so, they also shed light on the particular types of power or capital that pertain to each field. They observe that social capital, including networks in civil society and other fields, is especially important for coming into an elite position in Cambodian civil society.

Haryanto (2020), in his study of civil society elites in post-authoritarian Indonesia, also focuses on boundary crossers. The process of democratisation has stimulated movement from civil society to the state field. Haryanto (2020) identifies direct and indirect strategies that CSO leaders use to enter the state field. The direct 
strategy is one of running in legislative or executive elections, whereas the indirect strategy implies zig-zagging between civil society sub-fields before entering the state field, while sometimes also remaining active within civil society. When civil society leaders are transformed into politicians and state officials, they get new ways of shaping public policy. At the same time, they may also lose some capital through the boundary crossing.

Whereas Haryanto (2020) and Norén-Nilsson and Eng (2020) explore boundary crossing from civil society to electoral politics and the state field, Gulbrandsen (2020) provides an analysis of how business elites take up positions within civil society. Based on a survey of Norwegian elites he finds that it is not uncommon for business leaders to become elected representatives in CSOs. This indicates that CSOs to some extent are integrated into the general network of the Norwegian business elite. Business leaders with a working-class background are more frequently engaged in civil society than business leaders with a more privileged background.

Two of the articles in this thematic issue focus on think tanks, a type of civil society actor that is often perceived as more elitist. Think tanks are typically small, professional and expert-based, without any larger membership base. They tend to have more financial and knowledge resources and more political influence than other civil society actors. Åberg et al. (2020) examine Swedish think tanks, and more specifically their executives and top-level staff. Many of these 'think tankers' have a background in business, politics, media or the academia, indicating that boundary crossing is a common phenomenon. The organizational identity of think tanks is strikingly similar, despite differences in age, size and political affiliation. Jezierska (2020) describes Polish think tanks as a "reluctant civil society elite" (p. 152). Interviews with think tank leaders reveal not only a denial of being elitist, but some also deny that they are part of civil society and some even reject the think tank label.

While these contributions indicate common patterns across highly different social, political and cultural contexts, research on civil society elites is still in an early phase. With this thematic issue we invite more scholarly conceptual debates on the forms of capital that can be seen as constitutive of a civil society field and hence offering some actors domination over others. We also encourage more comparative efforts across country contexts to be able to identify similarities as well as differences and more profoundly identify the mechanisms and factors that institutionalise power in civil society and allow some actors to occupy leading positions. This also indicates the need for more substantial academic investigations into how civil society elites emerge and to what extent the pathways that lead into positions of power within civil society are the same as in politics or business. Are the structural advantages similar, or is civil society a differ- ent field or sector, marked by its own logic that has so often been argued by civil society scholars?

\section{Acknowledgments}

This thematic issue draws on work in a research program on civil society elites in Europe funded by Riksbankens Jubileumsfond, contract no. M17:0188:1, as well as in a research project on civil society elites in Cambodia and Indonesia funded by the Swedish Research Council, contract no. 2017-05583_3.

\section{Conflict of Interests}

The authors declare no conflict of interests.

\section{References}

Åberg, P., Einarsson, S., \& Reuter, M. (2020). Organizational identity of think tank(er)s: A growing elite group in Swedish civil society. Politics and Governance, 8(3), 142-151.

Gulbrandsen, T. (2020). Business elite as elected representatives in voluntary organizations in Norway. Politics and Governance, 8(3), 130-141.

Hartmann, M. (2007). The sociology of elites. London: Routledge.

Haryanto. (2020). Boundary crossers: The transformation of civil society elites in Indonesia's post-authoritarian era. Politics and Governance, 8(3), 120-129.

Jezierska, K. (2020). Three types of denial: Think tanks as a reluctant civil society elite. Politics and Governance, $8(3), 152-161$.

Khan, S. (2012). The sociology of elites. Annual Review of Sociology, 38, 361-377. https://doi.org/10.1146/ annurev-soc-071811-145542

Lay, C., \& Eng, N. (2020). State regulations and elitisation: A study of civil society elites in Indonesia and Cambodia. Politics and Governance, 8(3), 97-108.

Lindellee, J., \& Scaramuzzino, R. (2020). Can EU civil society elites burst the Brussels bubble? Civil society leaders' career trajectories. Politics and Governance, 8(3), 86-96.

Norén-Nilsson, A., \& Eng, N. (2020). Pathways to leadership within and beyond Cambodian civil society: Elite status and boundary-crossing. Politics and Governance, 8(3), 109-119.

Savage, M., \& Williams, K. (Eds.). (2008). Elites: Remembered in capitalism and forgotten by social sciences. Sociological Review, 56(1), 1-24.

Scott, J. (1996). Stratification and power: Structures of class, status and command. Cambridge: Cambridge University Press.

Scott, J. (2008). Power and the reconceptualization of elites. The Sociological Review, 56(1), 25-43. 


\section{About the Authors}

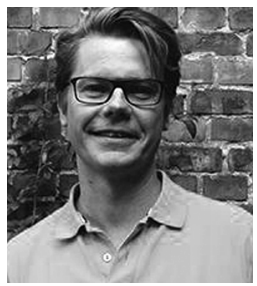

Håkan Johansson is a Professor of Social Work at Lund University, Sweden. His research focuses, among other things, on civil society, influence and advocacy, problems related to civil society service production and online mobilization. He has been engaged in studies of Europeanization of civil societies, climate demonstrations as well as local civil society regimes, and has published in Voluntas, Voluntary Sector Review and New Media and Society and edited volumes with Palgrave, Routledge and other publishers. Currently he leads a comparative six-year program on civil society elites (see www.civilsocietyelites.lu.se).

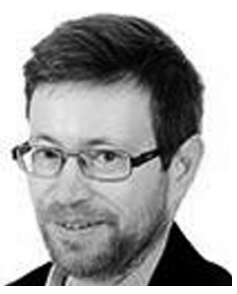

Anders Uhlin is Professor of Political Science at Lund University, Sweden. His research focuses on civil society activism, problems of democratization, and global and regional governance institutions. His works have appeared in journals such as Cooperation and Conflict, Democratization, Global Governance, Global Society, International Political Science Review, Journal of Civil Society and Third World Quarterly. He has published several research monographs and edited volumes. 